\title{
АНАЛИЗ ХИМИЧЕСКОГО ЗАГРЯЗНЕНИЯ РЕК БОЛЬШОЙ ЗЕЛЕНЧУК И КУБАНЬ В РАЙОНЕ ГОРОДА НЕВИННОМЫССК С 2012 ПО 2020 ГОДЫ
}

\section{ANALYSIS OF CHEMICAL POLLUTION OF THE BOLSHOY ZELENCHUK AND KUBAN RIVERS NEAR THE CITY OF NEVINNOMYSSK FROM 2012 TO 2020}

\section{Chadova \\ T. Zelenskaya \\ E. Stepanenko \\ S. Okrut \\ V. Khalikova}

Summary. The article presents an analysis of changes pollutant's concentration in Kuban and Bolshoy Zelenchuk rivers in the city of Nevinnomyssk in the period from 2012 to 2020. Particular emphasis is placed on the toxicological characteristics of chemicals whose maximum permissible concentrations are exceeded several times. The reasons and possible ways to improve the current environmental situation are considered.

Keywords: chemical pollution of rivers, discharges, sewage, Kuban River, Bolshoy Zelenchuk River.
Чадова Инна Николаевна

К.б.н., дочент, ФГБОУ ВО «Ставропольский государственный аграрный университет» innachadova@yandex.ru

Зеленская Тамара Георгиевна

К.с.-х.н., доцент, ФГБОУ ВО «Ставропольский государственный аграрный университет» tamara.zelenskaya2016@yandex.ru

Степаненко Елена Евгеньена К.б.н., дочент, ФГБОУ ВО «Ставропольский государственный аграрный университет» elenapstepanenko@yandex.ru

Окрут Светлана Васильевна К.б.н., дочент, ФГБОУ ВО «Ставропольский государственный аграрный университет»

s0kr@yandex.ru

Халикова Валерия Алексеевна

Ассистент, ФГБОУ ВО «Ставропольский государственный аграрный университет» valeriya.halikova22@gmail.com

Аннотация. В статье представлен анализ изменения концентрации загрязняющих веществ рек Кубань и Большой Зеленчук в период с 2012 по 2020 годы. Особый акцент сделан на токсикологической характеристике химических веществ, предельно допустимые концентрации которых превышены в несколько раз. Рассмотрены причины и возможные пути улучшения создавшейся экологической ситуации.

Ключевые слова: химическое загрязнение рек, сбросы, сточные воды, Кубань, Большой Зеленчук.

стве работ, посвященных проблеме гидрохимического состава Кубани, наибольшее внимание уделяется ее среднему и нижнему течению, тогда как работы, касающиеся верхнего течения единичны $[8,9]$. Кроме того, Невинномысск имеет статус промышленной столицы Ставропольского края, специализирующейся, преимущественно, на производстве химической продукции. Градообразующим предприятием является «Невинномысский Азот». Среди других крупных промышленных организаций следует отметить «Арнест», «Еврохим», Невинномысскую ГРЭС, «СтавСталь», мусоросортировочный завод «Перспектива», «Невинномысский маслоэкстракционный завод», «Птицекомбинат» и т.д. Столь интенсивное производство обуславливает значительную подверженность окружающей природной 
Таблица 1. Кратность превышения токсичными химическими веществами ПДК в реке Большой

Зеленчук (г. Невинномысск) (период с 2012 по 2020 г.)

\begin{tabular}{ll|l|l|l|l|l|l|l|l|l|l|}
$\begin{array}{l}\text { Хим. } \\
\text { соед. }\end{array}$ & 2012 & 2013 & 2014 & 2015 & 2016 & 2017 & 2018 & 2019 & 2020 \\
\hline & \multicolumn{2}{l|l}{ Кратность превышения пдк } \\
\hline Соединения меди & 15 & 3 & 3 & 3 & 3 & 3 & 5 & 3 & 2 \\
\hline Соединения железа & 2 & - & - & 2 & 3 & 3 & 3 & 12,5 & 6,5 \\
\hline Соединения цинка & 1,5 & - & - & - & - & - & - & - & - \\
\hline Фенолы & - & - & - & - & - & - & - & 2 & - \\
\hline
\end{tabular}

среды города, в том числе ее гидрологической составляющей, промышленной нагрузке $[10,11]$. В этой связи на Невинномысск возлагается особая ответственность по обеспечению природоохранных мер.

Основную функцию по очистке хозфекальных, производственных, а также ливневых сточных вод города возлагает на себя предприятие «Азот». Однако в городе имеется несколько организованных выпусков ливневых стоков в Кубань, в которые вода сбрасывается без предварительной очистки. Кроме того, периодически отмечается неконтролируемый сброс хозфекальных сточных вод частного сектора в ливнеотводящие канавы и затем в ливневые коллекторы. До сих пор открытым остается вопрос о строительстве очистных сооружений ливневых стоков. Другой важной проблемой города является недостаточный мониторинг качества воды: если раньше систематический контроль осуществлялся гидрометслужбой в постоянных створах, то на данный момент в регулярном режиме он не производится.

После переформирования ряда природоохранных органов, произошедшего в 80-х годах, отбор проб и выполнение анализов происходит преимущественно по заявкам Росприроднадзора и Ростехнадзора, а также на договорной основе в отношении объектов, не имеющих своего контроля за сбросами сточных вод. Лаборатории, существующие на крупных предприятиях, сами ведут отбор и анализ проб, а ливневые сбросы, включающие также сточные воды некоторых предприятий, никак не контролируются. Естественно, такое положение дел негативно сказывается на достоверности информации о загрязнении рек Кубань и Большой Зеленчук. В свою очередь это приводит к злоупотреблению данной ситуацией предприятиями, незаконно сбрасывающими в реки сточные воды с содержанием токсичных элементов, объем которых в разы превышает допустимые нормативы [7]. Таким образом, в Невинномысске существует проблема не только недоста- точно качественной очистки сточных и ливневых вод, попадающих в Кубань и Большой Зеленчук, но и отсутствия регулярно получаемых достоверных данных об их химическом составе. Учитывая вышесказанное, а также рост числа предприятий в городе, интерес для оценки экологического состояния рек Кубань и Большой Зеленчук представляет выявление тенденций изменения содержания в них токсичных химических элементов, превышающих предельно допустимые концентрации, за последнее годы. В связи с этим цель данной работы - анализ химического загрязнения рек Большой Зеленчук и Кубань в г. Невинномысске за период 2012-2020 г.

В статье приведена сравнительная оценка количественных показателей токсичных веществ рек Большой Зеленчук и Кубань (г. Невинномысск) (данные Росгидромет) [6], превышающих предельно допустимые концентрации (ПДК) в два или несколько раз, в период с 2012 по 2020 г. В расчет взяты вещества, присутствие которых обусловлено поступлением в водный объект преобладающих загрязнений отдельных видов сточных вод.

Из таблицы 1 следует, что наибольшего уровня загрязнения химическими веществами река Большой Зеленчук достигла в 2012 году, а также в 2018-2020 годы. При этом если медь и железо являлись наиболее часто регистрируемыми в течение исследуемого периода загрязнителями Большого Зеленчука, то превышения концентрации цинка больше не отмечалось. К 2018 году уровень соединений меди в реке увеличился до 5 ПДК с последующим снижением до начальных (3 ПДК) и более низких отметок в 2019-2020 годы. В 2019 году сильно возросло содержание железа (до 12,5 ПДК), а также впервые за анализируемый промежуток времени выявилось превышение нормативных показателей концентрации фенолов в реке. Количество соединений железа в 2020 в Большом Зеленчуке по сравнению с предыдущим годом несколько снизилось, хотя также оставалось высоким. 
Таблица 2. Кратность превышения токсичными химическими веществами ПДК в реке Кубань (г. Невинномысск) (период с 2012 по 2021 г.)

\begin{tabular}{|c|c|c|c|c|c|c|c|c|c|}
\hline $\begin{array}{l}\text { Хим. } \\
\text { соед. }\end{array}$ & 2012 & 2013 & 2014 & 2015 & 2016 & 2017 & 2018 & 2019 & 2020 \\
\hline & \multicolumn{9}{|c|}{ Кратность превышения ПДК } \\
\hline Соединения меди & 4 & 4,5 & 3 & 3 & 4 & 4 & 3 & 5 & 3 \\
\hline Соединения железа & 2 & - & - & 2 & 3 & 3 & 3 & 12 & 6 \\
\hline Соединения цинка & - & 3 & 2 & - & - & - & - & - & - \\
\hline Фенолы & - & - & - & - & - & - & - & - & 2 \\
\hline Сульфаты & - & - & - & 2 & 2 & 2 & - & - & - \\
\hline
\end{tabular}

Наиболее выраженное загрязнение реки Кубань соединениями меди и особенно соединениями железа зафиксировано в 2019-2020 г. (табл. 2). Кроме того, в 2020 году концентрация фенолов, которая ранее в течение исследуемого периода не превышала норму, возросла до 2 ПДК. До этого периода содержание меди в реке не превышало 3-4 ПДК, железа - 2-3 ПДК. При этом в относительно «чистые» по большинству показателей 2013-2014 годы в Кубани также отмечалось повышенное содержание цинка до 2 и 3 ПДК, а в 20152018 годах - увеличение сульфатов до 2 ПДК.

Таким образом, в водах Большого Зеленчука и Кубани в районе г. Невинномысска за последние годы значительно превышены нормативы содержания соединений железа, двукратно по сравнению с пороговым значением безопасности возросла концентрация фенола и в несколько раз - соединений меди (только в р. Кубань). Установленные тенденции являются тревожным сигналом в отношении экологической ситуации на исследуемом участке бассейна Кубани и Большого Зеленчука, так как превышение нормального уровня указанных химических веществ несет угрозу как состоянию экосистем, так здоровью человека.

Негативное влияние соединений тяжелых металлов, поступивших в организм человека в избыточных количествах, обусловлено тем, что они образуют комплексы с компонентами клеток, аминокислотами, белками, блокируя ферментные системы, участвующие в энергетическом обмене, клеточном дыхании, окислительном фосфорилировании. В результате нарушается функция биологических мембран, внутриклеточных ферментов, усиливается перекисное окисление липидов, сопряженное с угнетением иммунного ответа [1]. Поступление больших доз железа в организм человека и животных подавляет всасывание других микроэлементов в тонком кишечнике (Cu, $\mathrm{Mn}$ и др. [2]. Избыток меди вызывает нарушения работы мозга, печени, вестибулярного аппарата, приводит к недостатку цинка в организме, порокам развития плода у беременных, а при очень больших содержаниях — к летальному ис- ходу [1]. Большое количество цинка, попавшего в организм, оказывает канцерогенное влияние и токсическое действие на сердце, кровь, гонады и другие органы [2].

Фенол обладает канцерогенным действием. При остром отравлении данным веществом наблюдаются ожоги рта, рвота, диарея, головная боль, понос, слабость, отек легких, понижение артериального давления, сердечно-легочная недостаточность, судороги. Хроническое отравление приводит к анорексии, поражению центральной нервной системы, нервным расстройствам, головным болям, потере сознания и параличу, поражениям печени, почек, органов дыхания и сердечно-сосудистой системы. Фенол ухудшает санитарное состояние водоемов, изменяя режим потребления биогенных элементов и растворенных газов, тем самым оказывая негативное влияние на живые организмы [5].

Источниками данных видов загрязнений в реке Кубань и Большой Зеленчук можно считать сточные воды различных видов (в первую очередь, химической) промышленности, сельское и жилищно-коммунальное хозяйство, а причинами - перегрузку очистных сооружений, отсутствие элементов доочистки и очистных сооружений на ряде промышленных и коммунальных объектов $[3,4]$.

Таким образом, учитывая повышенное содержание токсичных компонентов в Большом Зеленчуке и Кубани (г. Невинномысск), следует более критично подойти к создавшейся на данной территории экологической ситуации. В этой связи для улучшения гидрохимического режима в реках г. Невинномысска предлагается решить вопрос с модернизацией очистительных систем, увеличить количество очистных сооружений ливневых стоков, а также установить несколько постоянных створов для отбора проб в целях получения точной, своевременной и достоверной информации о качественном состоянии вод. Это даст возможность проводить качественный анализ состояния воды в реках и своевременно регистрировать несанкционированные сбросы, а также применять к предприятиям-нарушителям административные меры. 


\section{ЛИТЕРАТУРА}

1. Авцин А.П., Жаворонков А.А., Риш М.А., Строчкова Л.С., Микроэлементозы человека, Медицина, Москва, 1991. 496 с.

2. Галимова А.Р., Тунакова Ю.А. Поступление, содержание и воздействие высоких концентраций металлов в питьевой воде на организм // Вестник Казанского технологического университета — Т. 16. — № 20.— 2013. — С. 165-169.

3. Дега Н.С., Байрамукова Ф.С., Борлаков М.С. Методологические основы гидрохимического мониторинга водного бассейна р. Кубани на территории Карачаево-Черкесской Республики // Международный научный журнал «Инновационная наука». Уфа: «Аэтерна».— 2015.— № 4.—C. 169-172.

4. Дега Н.С., Онищенко В.В., Борлаков М.С., Байрамукова Ф.С. Гидрохимическая трансформация реки Большой Зеленчук Карачаево-Черкесской республики в условиях интенсивного рекреационного освоения // Национальная ассоциация ученых (НАУ). Науки 0 Земле. — № 2 (7). - 2015. - C. 7-10.

5. Дементьева Д.М., Смольникова В.В., Дементьев М.С. К вопросу о загрязнении водоемов Ставропольского края тяжелыми металлами и нефтепродуктами // Известия Самарского научного центра Российской академии наук - Т. 12. — № 1(8). — 2010. — С. 2116-2118.

6. Ежегодник качества поверхностных вод Российской Федерации. Гидрохимический институт. Ростов-на-Дону. 2012-2020 г.

7. Знаенко А.Б., Чадова И.Н. Экологическая культура в природоохранной деятельности // Молодежь: образование, наука, экология — 2021. Сборник научных трудов по материалам Всероссийской научно-практической конференции, посвященной Дню Российской науки. Ставрополь.— 2021.— C. 101-106.

8. Никаноров А.М., Брызгало В.А., Решетняк О.С., Косменко Л.С., Кондакова М.Ю. Антропогенная трансформация экологического состояния и транспорт загрязняющих веществ по длине реки Кубани // Водное хозяйство России. — № 2. — 2013.— С. 108-118.

9. Никитина Т.А., Белан Е.В. Состояние водных экологических систем бассейна реки Кубань (среднее и нижнее течение) // Современные наукоемкие технологии. - 2010. — № 1.—C. 66-68.

10. Тенетилова Л.А. Вредные факторы среды обитания в современных условиях // Вестник Орловского государственного университета - 2016.№ 5.- С. 100-110.

11. Чадова И.Н. Оценка влияния отходов предприятий шерстяного производства на окружающую среду // Современная наука: актуальные проблемы теории и практики. Серия «Естественные и технические науки».— 2021.— № 7.— C. 43-45.

() Чадова Инна Николаевна ( innachadova@yandex.ru ), Зеленская Тамара Георгиевна ( tamara.zelenskaya2016@yandex.ru ),

Степаненко Елена Евгеньена ( elenapstepanenko@yandex.ru ), Окрут Светлана Васильевна ( s0kr@yandex.ru ),

Халикова Валерия Алексеевна ( valeriya.halikova22@gmail.com ).

Журнал «Современная наука: актуальные проблемы теории и практики»

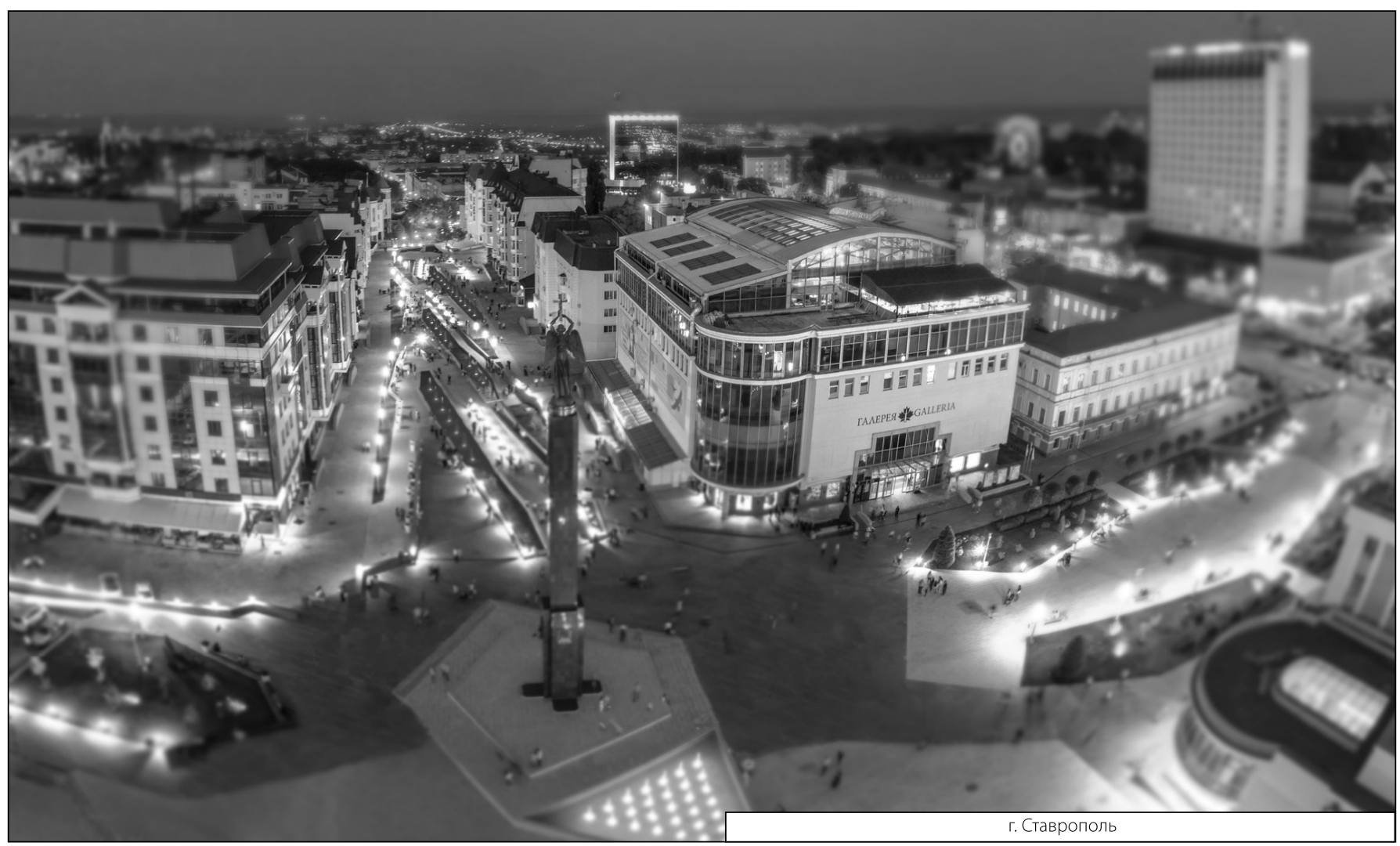

